\title{
Digital media use among older adults during the Covid-19 pandemic: a scoping
}

\section{review protocol}

\author{
O uso das mídlias digitais entre idosos durante a pandemia de Covid-19: protocolo de revisão de \\ escopo
}

El uso de medios digitales entre adultos mayores durante la pandemia Covid-19: protocolo de revisión del alcance

Received: 09/22/2021 | Reviewed: 09/26/2021 | Accept: 09/27/2021| Published: 09/29/2021

\author{
Juliana Cordeiro Carvalho \\ ORCID: https://orcid.org/0000-0002-4949-5046 \\ State University of Campinas, Brazil \\ E-mail: julianacordeirocarvalho89@gmail.com \\ Gabriela Cabett Cipolli \\ ORCID: https://orcid.org/0000-0002-6966-1654 \\ State University of Campinas, Brazil \\ E-mail: gabicipolli@hotmail.com \\ Vanessa Alonso \\ ORCID: https://orcid.org/0000-0002-0578-8971 \\ State University of Campinas, Brazil \\ E-mail: va-alonso@hotmail.com \\ Meire Cachioni \\ ORCID: https://orcid.org/0000-0001-5220-410X \\ University of São Paulo, Brazil \\ State University of Campinas, Brazil \\ E-mail: meirec@usp.br
}

\begin{abstract}
Objective: To identify the purpose of digital media use among older adults during the Covid-19 pandemic. Methodology: The indexed literature published in English, Spanish and Portuguese will be systematically searched on 7 databases; the references of studies included will be searched manually. Two authors will independently evaluate titles, abstracts and full-texts according to eligibility criteria. A customized data extraction form will be used to chart the data extracted from the studies. For consideration, studies must be in English, Portuguese or Spanish; involve older adults aged $\geq 55$ years (or mean age 60 years); assess older adults who used digital media during the Covid-19 pandemic; be empirical studies with qualitative or quantitative data, have crosssectional or longitudinal design, be letters to the Editor and editorials, and be published between the end of 2019 and 2021. Results: Results will be charted in a table and accompanied by a narrative summary.
\end{abstract}

Keywords: Digital media; Information technology; Coronavirus infections; Novel Coronavirus pandemic; Older adult.

\section{Resumo}

Objetivo: Identificar a finalidade do uso de mídias digitais entre idosos durante a pandemia de Covid-19. Metodologia: A literatura indexada publicada em inglês, espanhol e português será sistematicamente pesquisada e coletada em 7 bases de dados; as listas de referência dos estudos incluídos serão pesquisadas manualmente. Dois autores avaliarão os títulos, resumos e textos completos de forma independente de acordo com os critérios de elegibilidade. Um formulário de extração de dados customizado será utilizado para realizar a extração de dados dos estudos incluídos, que serão: estudos em inglês, português e espanhol; estudos envolvendo pessoas com 55 anos ou mais (ou com média de idade de 60 anos); estudos com idosos que usaram mídias digitais durante a pandemia de Covid-19; estudos empíricos com dados qualitativos ou quantitativos, transversais ou longitudinais, cartas ao editor e editoriais publicados entre o final de 2019, 2020 e 2021. Resultados: Os resultados serão apresentados em formato tabular, acompanhado de resumo narrativo.

Palavras-chave: Mídia digital; Informação tecnológica; Infecção por Coronavírus; Pandemia do novo Coronavírus; Idoso.

\section{Resumen}

Objetivo: Identificar el propósito del uso de medios digitales entre los ancianos durante la pandemia de Covid-19. Metodología: La literatura indexada publicada en inglés, español y portugués se buscará y recopilará 
sistemáticamente en 7 bases de datos; Se realizarán búsquedas manuales en las listas de referencias de los estudios incluidos. Dos autores evaluarán de forma independiente los títulos, resúmenes y textos completos de acuerdo con los criterios de elegibilidad. Se utilizará un formulario de extracción de datos personalizado para realizar la extracción de datos de los estudios incluidos, que serán: estudios en inglés, portugués y español; estudios en los que participaron personas de 55 años o más (o con una edad media de 60 años); estudios de personas mayores que utilizaron medios digitales durante la pandemia de Covid-19; estudios empíricos con datos cualitativos o cuantitativos, transversales o longitudinales, cartas al editor y editoriales publicados entre finales de 2019, 2020 y 2021. Resultados: Los resultados se presentarán en formato tabular, acompañados de un resumen narrativo.

Palabras clave: Medios digitales; Información tecnológica; Infección por coronavirus; Nueva pandemia de coronavirus; Anciano.

\section{Introduction}

The Covid-19 pandemic has imposed social isolation on everyone. However, although physically isolated, people can remain close through digital communication (Couto \& Cruz, 2020). Videocalls can expand social circles and increase the frequency of virtual meetings with family members, for instance (Noone et al, 2020),

Internet access provides a means of shopping online, engaging in physical exercise programs, taking part in medical teleconsultations, classes, among countless other activities, without leaving home (Seifert, 2020). Compared with previous pandemics, such as the Spanish Flu, Covid-19 differs by involving technological and digital accessibility to a contingent of the population (Henrique, 2020). However, while digital media - defined as the group of digitally-based communication vehicles and devices allowing digital distribution or communication of visual, audio or written works (Miskolci, 2011) - has become available globally, empirical studies reveal a digital gap between younger and older adults (Hunsaker \& Hargittai, 2018).

Many older people encounter difficulties dealing with new communication tools (Rivinen, 2020) and are averse to using or learning about them, referred to as "technophobia" (Nimrod, 2018). Older and more physically frail adults are not online and have to cope with a double burden of digital and social exclusion. This vulnerability can negatively impact access to digital services and content, such as health information, digital social events, social networks and on-line shopping (Seifert, Cotten \& Xie, 2020).

In the context of the pandemic, even with the difficulties and limitations involving the older population and digital world, Nascimento (2020) and Siette et al. (2021) point out that the digital tools most used by older adults to obtain information about Covid-19 are the radio and television. Chein et al. (2021) added that technologies such as the telephone, internet and e-mail are used by older adults to search for information, maintain social connectedness and to shop.

The results of the study by Chein et al. (2021) also showed that many participants used online communication platforms (e.g. Facebook) and online videoconferencing apps (e.g. Zoom) to help keep connected with their family members and friends during the course of the pandemic. Thus, difficulty using digital media clearly does not apply to all older people, and it is important to identify which type of media is being used and what are the limitations cited by older adults for not using certain types of digital media. To address this gap in the literature, the objective of the proposed review will be to identify the purpose of digital media use among older adults during the Covid-19 pandemic.

The objective of this scoping review is to provide an overview of the available literature on the purpose of digital media use by older adults during the Covid-19 pandemic.

\section{Methodology}

A scoping review is suited to summarizing and disseminating the search results and identifying gaps in the available literature. This type of review can also address broader topics where a variety of study designs may be applicable (Arksey \& O'Malley, 2005). 
During the Covid-19 pandemic, governments all over the world have implemented different levels of public health strategies, such as barriers, social distancing, application of diagnostic tests for the disease, contact tracing and physical isolation measures (Anderson, et al, 2020). As a result, the use of digital technology as a means of tackling the crisis and providing socioeconomic continuity has soared. For example, people are using technology to practice home-working, chat with family members and loved ones, and for entertainment and information purposes (Chen et al, 2020; Brooks et al, 2020).

Despite the unexpected nature of the crisis and greater vulnerability associated with age, inequality in digital technology among age groups may lead to low use or poor exploitation of services that promote well-being of older individuals, exacerbating the existing inequality (Souter, 2020). Amid this new framework of social roles and innovative ways of tackling transmission and halting the pandemic, a better understanding of digital involvement of the older population can shed light on efforts to render technology equitable.

Although the growing role of digital media in health communications has been well documented, scant empirical data is available on how older adults use digital media for learning purposes and to keep abreast of ongoing health crises (Neely, Eldredge \& Sanders, 2021).

Academic research is crucial in helping support older adults to improve their digital literacy. Future studies should explore the use of technologies by older adults in more depth. Gaining a better understanding of these mechanisms is crucial for professionals and other stakeholders to determine the forms of leverage at their disposal for supporting older adults online (Moore \& Hancock, 2020).

The planned scoping review shall be conducted according to the framework devised by Arksey and O'Malley (2005) and subsequently developed by Levac et al. (2010) and also the methodology for the Joanna Briggs Institute (JBI) (2021) scoping review. The scoping review methods shall comprise the following key stages: (1) identification of review questions; (2) identification of relevant studies; (3) selection of studies; (4) mapping/charting of data; and (5) comparison, summary and reporting of results (Arksey \& O'Malley, 2005) (Peters et al, 2015). The Preferred Reporting Items for Systematic Reviews and Meta-Analyses scoping reviews extension (PRISMA-ScR) (Tricco et al, 2018) checklist will be employed, as shown in Table 1.

\section{Stage 1: identification of review questions}

The following broad review question will guide the strategy for the systematic search of the literature: 'What is the main purpose of digital/social media use by community-dwelling older adults during the Covid-19 pandemic?'. This question should provide a sufficiently comprehensive review of the relevant literature available, while also allowing the addition or refinement of questions guiding the search during the course of the study, as needed. During the preliminary exploratory review, only one secondary question was identified for guiding subsequent stages of the scoping review and complementing the broader question defined above. This question shall include, but not be limited to:

1. Which types of media had greatest uptake and/or acceptance by the older adults during the Covid-19 period?

\section{Stage 2: Identification of Relevant Studies}

The initial search strategy (Aged OR “Aged, 80 and over” OR “Seniors” OR “Older People” OR “Older Adults”) AND ("Digital Media" OR "Social Media” OR "Social Networking” OR “Online Social Networking” OR "Internet Use” OR “Internet Access" OR “Mass Media” OR “Information Technology”) AND ((“Coronavirus Infection” OR “Covid-19”) AND Pandemics) was developed with the support and assistance of a specialist librarian. The databases to be searched as part of the review shall include: Pubmed, Ageline, SCOPUS, LILACS, EMBASE, PsyNET and Web of Science. The literature search 
strategy will be devised using medical science headings (MeSH-terms) and text words related to the study population, concept and context.

The population, concepts and context (PCC) framework recommended by the Joanna Briggs Institute (JBI, 2021) scoping review analyses will be used to determine the review question and eligibility criteria. Studies will be selected according to inclusion criteria. Thus, the scoping review shall include studies involving subjects aged $\geq 55$ years, men and/or women (mean age, 60 years) [participants]. The review shall search gerontology literature that reports the use of digital media by older adults, including all synonyms for both terms [concept]. This review shall encompass studies involving communitydwelling older adults [context].

The scoping review will consider all relevant studies published in English, Portuguese or Spanish. The search will include empirical studies based on qualitative or quantitative data, cross-sectional or longitudinal studies, letters to the Editor, published during the period spanning from December 2019 up to July 2021. Reviews, protocols, book chapters and guidelines will not be included in the scoping review.

\section{Stage 3: Selection of Studies}

Two authors will select the studies based on the inclusion criteria and by using Rayyan (https://rayyan.qcri.org/welcome) - a web and mobile application for conducting systematic reviews, analyzing titles and abstracts of articles. The initial screening process will involve reading of titles and abstracts to determine the following: (1) if at least one of the reviewers agrees to include or deems the abstract or title inconclusive, the study shall be retained for the second level of screening; (2) if both reviewers decide a study is not eligible for inclusion, the article will be excluded. All studies at this level will be registered by both reviewers on Rayyan. The inclusion criteria for the present review will observe the PCC framework, as recommended for guiding scoping reviews ${ }^{23}$. Studies with the following characteristics will be considered for the review:

- $\quad$ studies involving older adults ( $\geq 55$ years), men and/or women (mean age 60 years) [participants];

- gerontology literature describing social media use by older adults during the Covid-19 pandemic [context];

- studies involving community-dwelling older adults [concept].

- studies with a variety of study designs (cross-sectional, longitudinal, quantitative, qualitative, letters to Editor). The following types of papers will be excluded:

- publications categorized as gray literature (i.e. books, theses, dissertations);

- case-control studies, interventions and reviews, guidelines, commentaries or opinion articles.

\section{Stage 4: Mapping/Charting of Data}

Data relevant to this review will be extracted from the studies included by the 2 independent reviewers using the methods recommended by Peters et al. (2015). The data extraction will include the variables author(s), year of publication, article title, type of study, aims, sample size, population characteristics (mean age (when reported), gender), methods, instruments used, social media used by older adults, and results (https://osf.io/jpzbw). Analysis of the articles selected shall determine the robustness of the study methodology, the statistical analyses employed to determine uptake/acceptance of social media during the Covid-19 pandemic, and whether validated instruments were used in the study. 


\section{Stage 5: Comparing, Summarizing and Reporting of Results}

The review decision process will be presented in the form of a flow diagram, indicating the results from the search, removal of duplicate citations, study selection stages (title/abstract and full-text), reasons for article exclusion after full-text assessment, and final number of studies included. This process will be detailed using a PRISMA flow diagram (JBI, 2015). The results will be presented in a charting table, together with a narrative summary of the objective of the present scoping review. Based on the data extracted, a draft charting table will be developed, with data grouped by study type.

\section{Ethical approval}

Since the scoping review methodology aims to synthesize information from available publications, this study requires no ethical approval.

\section{Partial Considerations}

\section{Relevance and Dissemination}

This scoping review could help inform researchers on the main purpose of digital media use by older adults during the Covid-19 pandemic. The results of the study could also help identify the types of digital media most commonly used by older adults and ascertain the level of uptake and acceptance of digital media among older people during the pandemic period. The full scoping review will be disseminated by means of presentations at conferences on aging and via publications in international peer-reviewed journals.

As the world population is aging associated with the advancement of the technologies, an example of the use of digital media, it is likely that new research and work will emerge that address issues in which they identify what are the limitations of older elderly people in the use of digital media and thus try to remedy them. It is worth remembering that the objective is to try to identify barriers and thus make this tool more accessible and easy to use for the elderly.

\section{Acknowledgments}

The authors gratefully acknowledge the contribution of Ana Paula Morais e Oliveira, a librarian at the Universidade Estadual de Campinas (Brazil), for her specialized support during the search process.

\section{References}

Arksey, H. \& O'Malley, L. (2005). Scoping studies: para um quadro metodológico. Int J Soc Res Methodol., 8 (1): 19-32.

Anderson, R. M., Heesterbeek, H., Klinkenberg, D. \& Hollingsworth, T.D. (2020). How will country-based mitigation measures influence the course of the Covid-19 epidemic? The Lancet, 395 (10228): 931-934.

Brooks, S. K., Webster, R. K., Smith, L. E., Woodland L, Wessely S \& Greenberg N, et al. (2020). The psychological impact of quarantine and how to reduce it: rapid review of the evidence. The Lancet, 395 (10227): 912-920.

Chein, A. T, Ge, S., Cho, S., Teng, A. K., Chu, F., Demiris, G. \& Zaslavsky, O. (2021). Reactions to Covid-19, information and technology use, and social connectedness among older adults with pre-frailty and frailty. Geriatr. Nurs, 42 (1): 188-195.

Chen, X., Zhou, X., Li, H., Li, J. \& Jiang, H. (2020). The value of WeChat as a source of information on the Covid-19 in China. [Preprint]. Bull World Health Organ, 30 .

Couto, E. S. \& Cruz, I. M. P. (2020). \#Fiqueemcasa: educação na pandemia da covid-19. Interfaces Científicas, 8 (3), 200 - 217.

Henrique, T. (2020). Covid-19 e a Internet (ou estou em isolamento social físico). Revista Interfaces Científicas - Humanas e Sociais, 8 (3).

Hunsaker, A. \& Hargittai, E. (2018). A review of internet use among older adults. New Media \& Society, 20 (10), 3937-3954.

JBI Global Wiki. Manual do Revisor JBI. JBI Global Wiki. https://reviewersmanual.joannabriggs.org/. 
Research, Society and Development, v. 10, n. 12, e520101220916, 2021

Joanna Briggs Institute. The Joanna Briggs Institute reviewers' manual 2015: methodology for JBI scoping reviews. Adelaide: Joanna Briggs Institute.

Levac, D., Colquhoun, H., O'Brien, K. K. (2010). Estudos de escopo: avançando na metodologia. Implement Sci., 5 (69).

Miskolci, R. (2011). Novas conexões: notas teórico-metodológicas para pesquisas sobre o uso de mídias digitais. Cronos, v. 12 (2), 09-22.

Moore, R. C., Hancock, J. T. (2020). Older adults, social technologies, and the coronavirus pandemic: challenges, strengths, and strategies for support. Social Media. + Society, 1-5.

Nascimento, M. M. (2020). Covid-19: U3A students' report on the impacts of social isolation on physical and mental health and access to information about the virus during the pandemic. Educational Gerontology, 46 (9): 499-511.

Neely, S., Eldredge, C., Sanders, R. (2021). Health information seeking behaviors on social media during the covid-19 pandemic among american social networking site users: survey study. J. Med. Internet Res., 23 (6).

Nimrod, G. (2018). Technophobia among older Internet users. Educational Gerontology, 44 (2-3): 148-162.

Noone, C., McSharry, J., Smalle, M., Burns, A., Dwan, K., Devane, D. \& Morrissey, E.C. (2020). Video calls for reducing social isolation and loneliness in older people: a rapid review. Cochrane Database of Systematic Reviews, 5.

Peters, M. D. J., Godfrey, C. M., Khalil, H., McInerney, P., Parker, D. \& Soares, C. B. (2015). Guidance for conducting systematic scoping reviews. Int. J. Evid. Based Health, 13 (3): 141-6.

Rivinen, S. (2020). Media education for older people - views of stakeholders. Educational Gerontology, 46 (4): $195-206$.

Seifert, A. (2020). The Digital Exclusion of Older Adults during the Covid-19 Pandemic. J Gerontol Soc Work, 63 (6-7): 674-676.

Seifert, A, Cotten, S. R. \& Xie, B. (2020). A Double Burden of Exclusion? Digital and Social Exclusion of Older Adults in Times of Covid-19. Journals of Gerontology: Social Sciences, 20 (20).

Siette, J., Dodds, L., Seaman, K., Wuthrich, V., Johnco, C., Earl, J., Dawes, P. \& Westbrook, J. I. (2021). The impact of Covid-19 on the quality of life of older adults receiving community-based aged care. Australas J Ageing, 40 (1): 84-89.

Souter, D. (2020). Inside the Digital Society: Inequality, the internet and the corona crisis.: Association for progressive communication London. URL: https://www.apc.org/en/blog/inside-digital-society-inequality-internet-and-corona-crisis.

Tricco, A. C., Lillie, E., Zarin, W., O'Brien, K. K., Colquhon, H. \& Levac, D., et al. (2018). Extensão PRISMA para revisões de escopo (PRISMA-ScR): Lista de verificação e explicação. Ann Intern Med., 169 (7): 467-73. 